\title{
Epidural Injection of Extended-Release Morphine During Colorectal Surgery
}

\author{
Sung-Bum Kang \\ Department of Surgery, Seoul National University College of Medicine, Seoul National University Bundang Hospital, Seongnam, Korea
}

\section{See Article on Page 186-191}

Postoperative pain is one of the most serious symptoms in cancer patients. However, many patients receive inadequate pain management despite the existence of established pain treatment guidelines [1]. Normally, pain is not a surgeon's primary concern [2]. However, with enhanced recovery programs and laparoscopic surgery, optimal pain management is a key factor in postoperative care and leads to an improvement in physical performance and pulmonary functions and to a decrease in the length of the hospital stay [3].

Until recently, the optimal duration or route for pain control was not considered during randomized trials [4] and still remains a controversial issue. Peravali described a case series of 280 patients who had undergone open and laparoscopic colorectal procedures under a single epidural injection of extended-release morphine, DepoDur $^{\circledR}$ [5]. These patients had neither an epidural catheter nor an epidural infusion pump. In addition, approximately $30 \%$ of all patients did not require any additional opiate analgesia, and only $12 \%$ required patient-controlled analgesia at 48 hours [5]. DepoDur $^{\circledR}$ has been used in various orthopedic, obstetric, and gynecological studies, which have demonstrated effective longlasting analgesia in the absence of large concentrations of opioids, as well as enhanced patient activity levels and satisfaction [6-8]. To our knowledge, this is the largest case series reporting the use of DepoDur ${ }^{\circledR}$ in colorectal surgery.

Peravali did not make direct comparisons with traditional epidural infusions or postoperative analgesics. However, these case

Correspondence to: Sung-Bum Kang, M.D.

Department of Surgery, Seoul National University College of Medicine, Seoul National University Bundang Hospital, 82 Gumi-ro 173beon-gil, Bundang-gu, Seongnam 463-707, Korea

Tel: +82-31-787-7093, Fax: +82-31-787-4055

E-mail: kangsb@snubh.org

(c) 2014 The Korean Society of Coloproctology

This is an open-access article distributed under the terms of the Creative Commons Attribution NonCommercial License (http://creativecommons.org/licenses/by-nc/3.0) which permits unrestricted noncommercial use, distribution, and reproduction in any medium, provided the original work is properly cited. series did highlight the advantages of extended-release epidural morphine with tolerable side effects, such as transient hypotension, respiratory compromise, pruritus, and nausea, in the context of colorectal surgery [9]. This prospective study provides an innovative technique for pain management in order to improve the outcomes of postoperative care in colorectal cancer patients and provides encouraging data that justify randomized controlled trails.

\section{REFERENCES}

1. Joshi GP, Beck DE, Emerson RH, Halaszynski TM, Jahr JS, Lipman AG, et al. Defining new directions for more effective management of surgical pain in the United States: highlights of the inaugural Surgical Pain Congress ${ }^{\mathrm{TM}}$. Am Surg 2014;80:219-28.

2. Von Roenn JH, Cleeland CS, Gonin R, Hatfield AK, Pandya KJ. Physician attitudes and practice in cancer pain management. A survey from the Eastern Cooperative Oncology Group. Ann Intern Med 1993;119:121-6.

3. Basse L, Raskov HH, Hjort Jakobsen D, Sonne E, Billesbolle P, Hendel HW, et al. Accelerated postoperative recovery programme after colonic resection improves physical performance, pulmonary function and body composition. Br J Surg 2002;89:446-53.

4. Lee SM, Kang SB, Jang JH, Park JS, Hong S, Lee TG, et al. Early rehabilitation versus conventional care after laparoscopic rectal surgery: a prospective, randomized, controlled trial. Surg Endosc 2013;27:3902-9.

5. Peravali R, Brock R, Bright E, Mills P, Petty D, Alberts J. Enhancing the enhanced recovery program in colorectal surgery: use of extended-release epidural morphine (DepoDur $\left.{ }^{\circledR}\right)$. Ann Coloproctol 2014:30;186-91.

6. Carvalho B, Riley E, Cohen SE, Gambling D, Palmer C, Huffnagle $\mathrm{HJ}$, et al. Single-dose, sustained-release epidural morphine in the management of postoperative pain after elective cesarean delivery: results of a multicenter randomized controlled study. Anesth Analg 2005;100:1150-8.

7. Viscusi ER. Emerging techniques in the management of acute pain: epidural analgesia. Anesth Analg 2005;101(5 Suppl):S23-9.

8. Hartrick CT, Martin G, Kantor G, Koncelik J, Manvelian G. Eval- 


\section{Coloproctology}

uation of a single-dose, extended-release epidural morphine formulation for pain after knee arthroplasty. J Bone Joint Surg Am 2006;88:273-81.

9. Gambling D, Hughes T, Martin G, Horton W, Manvelian G. A comparison of DepoDur ${ }^{\circledR}$, a novel, single-dose extended-release epidural morphine, with standard epidural morphine for pain relief after lower abdominal surgery. Anesth Analg 2005;100:106574. 